\title{
如何进行学生顶岗实习期间角色转变矛盾的化解一一中职学 生顶岗实习案例解析
}

\author{
吴征 \\ 江苏省溧水中等专业学校 \\ DOI:10.32629/mef.v2i8.194
}

[摘 要] 中职学校为社会培养实用型的技术工人,如何把学校的学生转变为企业的员工是中职教育的核心目标。中职学生进 行半年的顶岗实习, 作为角色转变的过渡。于是在企业顶岗实习的学生就有了双重身份。如何处理在此期间学生、家长对于 角色转变上的认识问题,是班主任对顶岗实习期间学生,进行教育管理的重要问题。

[关键词] 中职学生; 顶岗实习; 角色转变; 矛盾化解

\section{How to Solve the Contradiction of the Role Change During the Student's Internship - - Analysis of the Case of Internship for Secondary Vocational Students \\ Wu Zheng \\ Jiangsu Province Lishui Secondary Professional School}

[Abstract] Secondary vocational schools train practical and skilled workers for the society, how to transform the students of the school into employees of the enterprise is the core goal of secondary vocational education. Secondary vocational students conduct half-year internships as a transition to role change. Therefore, students who are internships in enterprises have a dual identity. How to deal with the problem of students and parents' understanding of the role change during this period is an important issue for the class teacher to carry out education management during the internship period.

[Key words] secondary vocational students; post internship; role change; contradictory solution

中职学校为社会培养实用型的技术工人, 把学校的学生 转变为企业的员工是中职教育的核心目标。中职学校在人才 培养方案中构建了顶岗实习平台, 安排了半年角色转变的过 渡时间, 于是在企业顶岗实习的学生有了双重身份：即是学 校的学生, 又是企业的员工。学校的核心任务是教育, 企业的 核心任务是生产 (工作或劳动), 两者虽不是相互对立的矛盾, 但也不是和谐对等的统一关系。顶岗实习过程中一旦出现状 况, 我们就必须辩明身份: 是学生还是员工?

事件: 原我班机电专业有三位学生根据个人和企业的双 向选择, 学校、学生、企业签订了三方协议后, 安排去了企业 顶岗实习。十天之后, 企业人事部门通知学校解除劳动关系 (顶岗实习), 退回学生, 理由 (书面) 是学生不能适应企业的 工作要求: 其中两位学生是不适应体力要求, 另一位学生是 不能适应工作环境 (工作岗位中要用酒精清洗设备, 因体质 特殊, 对其过敏)。

处理: (1) 了解真相: 得到学生被企业退回的消息, 第一 时间我向分管顶岗实习工作的学工处主任了解学生被退回 的核心原因: 企业主要领导巡查时发现学生在上班时间玩手 机, 责令主管部门强化顶岗实习学生的纪律要求, 主管部门 指出上班时间玩手机违反企业工作纪律后, 顶岗实习学生没 有改变, 企业主要领导在之后的巡查中又多次看到学生玩手
机, 最后责令人事部门解除劳动关系, 退回学生。(2) 发现问 题: 第二天 (退回) 通过召集学生进行交流座谈, 了解学生对 被企业退回的看法。在与学生的交流座谈中, 我发现学生对 双重身份的理解有错误, 认为在一个具体的事件中自己可以 是学生, 也可以是员工。问题一: 学生认为签订了三方协议, 我是企业的员工, 企业不能随便 (认为书面理由不成立) 开除 我们。问题二: 学生说他们午餐休息时间玩了一会儿手机, 那不是工作时间, 不影响工作。玩手机的行为即使违反了企 业的规定, 但他们是学生, 要以教育为主, 开除他们的处理太 严了。问题三: 我们是学校的学生, 我们对顶岗实习的安排 是认同的, 学校要恢复我们的顶岗实习。(3) 化解问题: 我在 与学生交流的过程中, 抓住认知 “双重身份” 核心点, 通过沟 通交流形成了认知共识。解答一: 协议不是合同, 是协商而 确定的约定, 因此不存在开除之说。企业只是针对你们解除 为学校提供顶岗实习平台而已, 即你们在企业劳动实践的活 动被终止了, 与学生的学籍没有关系 (学生担心会被开除学 籍)。解答二: 作为即将走上社会的中职学, 顶岗实习是中职 学生重要的学习内容 (任务), 内容的核心不是工作岗位的具 体任务, 而是融入企业 (社会) 的要素, 这些要素主要包括纪 律、责任、安全、质量等意识。玩手机不是简单的生活问题, 关联到企业的岗位的具体任务, 不仅影响工作时的体力 (基 
础能力), 还会影响到生产产品的质量问题, 更重要的是会引 发生产安全问题。企业给出的理由和事件的真相并不矛盾, 关注事件的合理性和规则性, 不如去发现我们在角色转变过 程中存在的问题。解答三: 企业只是顶岗实习的平台, 自己 找企业和学校找企业不冲突, 学校会根据需要安排学生再次 顶岗实习。企业的生产追求零差错, 越是正规的好企业, 越不 可能回收有问题的员工。从尊重企业的角度, 学校不会提出 返回要求。作为学生, 要清楚不解决自身存在的问题, 去任何 企业都有可能被退回。当下重要的是反思自己存在的不足。 (4) 共识扩散: 沟通交流后学生对问题有了新认知, 和我有了 共识。顶岗实习被企业退回不是学校对一个违纪事件的处理, 是企业向学校反馈学生不适应企业要求的信息, 学生要直面 问题, 审视自己的不足, 做好再出发的准备。我向学生提出要 求: 回家之后主动和家长谈谈顶岗实习发生的事, 说清事由 的同时与家长商谈一下下阶段顶岗实习意向。

延伸: 几日后的晚上, 其中有一位学生的父亲打电话给 我问询企业把他家小孩开除了是怎么回事? 家长跟我说: 玩 手机是不好, 但那只是个小错误, 处理学生要以教育为主, 怎 么好把学生开除了。我回复家长:（1）做为顶岗实习的学生, 企业通过一阶段的观察, 认为其不能适应企业岗位要求, 解 除了提供顶岗实习的协议承诺, 不是开除学生, 是把学生退 回学校, 由学校重新安排顶岗实习。(2) 玩手机在生活中只是 个不太好的习惯, 但关联到工作, 会引发安全问题。如果工作 中触发了工伤事故, 不仅企业要受到经济损失, 身体伤残对 学生家庭来说损害更为严重。企业重视工作纪律是防范突发 恶性事件发生的正常管理行为, 家长不要从生活的角度把玩 手机看作小事, 要从工作 (立足社会) 的角度协同学校引导子 女的成长。家长听了我的回复, 理解了学校和企业对事件的 处理, 表示先调整一下心态, 再积极自主寻找顶岗实习单位。

解析：学校教育通常把顶岗实习内涵分解为二个部分: (1) 顶岗实习是学生学业内容的重要部分, 与专业技能的综
合应用关联, 一般要求岗位与专业对口。(2) 顶岗实习是学生 到企业就业的过渡期, 校企之间的合作基础是就业关系。企 业接收学生顶岗实习动因主要有几个方面：A、预期或现实 的生产任务需要补充员工。B、为企业发展预备培养技术型 员工。C、构建巩固校企的合作关系 (学校的专业与企业的产 品关联度很高)。D、企业的岗位具有很强的流动性, 需要不 断补充。E、企业扩大规模需要招聘新员工。可以看出学校 眼中的顶岗实习和企业眼中的顶岗实习并不完全一致, 因此, 顶岗实习过程中会出现各种想不到的问题。让企业按照学校 的思路去做学校教育的事不现实也不可能, 中职学校把教育 的核心目标一一就业关联到企业的用工上是一个切实可靠 的教育途径, 因此顶岗实习关注学生的行为能力要比关注技 能水平更重要。提前做好就业认知教育对顶岗实习的工作来 说很重要, 我在学校顶岗实习前利用班会课和晨读课和学生 讲解以前学生顶岗实习中的现象和成因, 帮助学生认知顶岗 实习的内涵, 构建提升学生职业行为的基础能力。顶岗实习 前我还约请家长、学生一起谈谈顶岗实习的计划, 引导家长 和学生积极思考如何稳定有效立足社会? 构建学生对顶岗 实习的心理预期。有了前期的认知交流, 当顶岗实习中出现 的问题时, 化解问题就轻松多了。

[参考文献]

[1]田迎起.中职生顶岗实习现存问题及对策研究[J].河 北大学学报,2016(24):86

[2]范玉华.中职生顶岗实习面临的问题与解决对策 [J]. 职业技术,2014(08):36.

[2]任登安.中职生顶岗实习管理策略 [J]. 职业教 育,2013(09):52.

作者简介:

吴征(1981--), 男, 江苏金坛市人, 汉族, 本科, 讲师, 研究方 向：机电专业教育教学。 